\title{
Sensory stability of whole mango juice: influence of temperature and storage time
}

\author{
Estabilidade sensorial de suco integral de manga: influência da temperatura e do tempo de armazenamento
}

\author{
Anderson do Nascimento OLIVEIRA ${ }^{1}$, Afonso Mota RAMOS ${ }^{1 \star}$, \\ Valéria Paula Rodrigues MINIMํㅗㄹ José Benício Paes CHAVES ${ }^{1}$
}

\begin{abstract}
This study investigated the degradation kinetics of the sensory attributes of commercial whole mango (cv. Ubá) juice and evaluated its sensory acceptability during storage. Samples of the product were stored in a BOD incubator at 25,35 , and $45^{\circ} \mathrm{C}$ under 24 hours light ( 650 lux) for 120 days. Sensory analyses (Quantitative Descriptive Analysis - QDA) were conducted with trained panel and consumers. The correlations between sensory and physicochemical characteristics (instrumental color and vitamin $\mathrm{C}$ content) were also assessed. Flavor, aroma, and color vary with temperature and time of storage. Aroma and flavor were most affected by temperature with values of $\mathrm{Q}_{10}$ and $\mathrm{E}_{\mathrm{a}}$ equal to 4.16 and $25.31 \mathrm{kcal} . \mathrm{mol}^{-1}$; and 3.61 and $22.80 \mathrm{kcal}^{\mathrm{mol}}{ }^{-1}$, respectively. The sensory changes observed by the trained panel are related to the degradation of vitamin $\mathrm{C}$ and changes in the color coordinates $\left(\mathrm{L}^{*}\right.$ and $\Delta \mathrm{E}^{*}$ ) of mango juice. However, consumers were unable to detect changes in the overall quality of the juices. It was observed that the QDA can be a useful tool to assess shelf-life.

Keywords: Ubá mango; regression analysis; degradation kinetics; shelf-life.
\end{abstract}

\section{Resumo}

Este trabalho objetivou estudar a cinética de degradação dos atributos sensoriais do suco integral de manga Ubá comercial e avaliar sua aceitabilidade sensorial durante o armazenamento. Amostras do produto foram armazenadas em estufas tipo B.O.D a 25 , 35 e $45^{\circ} \mathrm{C}$, providas de iluminação (650 lux) 24 horas por dia, durante 120 dias. Foram realizadas análises sensoriais com provadores treinados (Análise Descritiva Quantitativa - ADQ) e com consumidores. Também foram avaliadas as correlações entre as características sensoriais e físico-químicas (cor instrumental e teor de vitamina C). Os atributos sabor, aroma e cor variaram com a temperatura e o tempo de armazenamento, sendo que o aroma e o sabor foram os mais afetados pela temperatura, com valores de Q10 e Ea iguais a 4,16 e 25,31 kcal.mol ${ }^{-1}$; e 3,61 e 22,80 kcal.mol-1, respectivamente. As alterações sensoriais observadas pela equipe treinada são relacionadas com a degradação de vitamina $\mathrm{C}$ e variações nas coordenadas de cor $\left(\mathrm{L}^{\star}\right.$ e $\left.\Delta \mathrm{E}^{\star}\right)$ do suco de manga. Entretanto, os consumidores não foram capazes de detectar alterações na qualidade global dos sucos. Observou-se que a ADQ pode ser uma ferramenta útil em estudos de vida de prateleira.

Palavras-chave: Manga Ubá; análise de regressão; cinética de degradação; vida de prateleira.

\section{Introduction}

The quality of food products is influenced by several aspects such as microbiological, nutritional, and sensory properties. However, sensory changes are not always desirable because even if the product still presents good nutritive and microbiological characteristics, it can be rejected by consumers before the other factors reach unacceptable levels.

Using human sense organs as measurement "instruments", sensory analysis enables the detection of certain changes in product quality that may be more difficult to be detected by conventional analytical methods or even through instrumental techniques (MATTIETTO; LOPES; MENEZES, 2007; MIGUEL et al., 2010). One of the most used techniques to quantify sensory changes during food storage is the Quantitative Descriptive Analysis (QDA) (VILANOVA; MASA; TARDAGUILA, 2009). It is used to identify, describe, and measure the intensity of the sensory properties of the product, as perceived by consumers (MASCARENHAS et al., 2010; MARANGONI; MOURA, 2011). In other words, QDA allows the accurate quantification of sensory characteristics in mathematical terms (MOSKOWITZ, 1988). Acceptance tests, in turn, enable the evaluation of the opinion of potential consumers of the product with respect to preference or acceptance; these tests are also very important in studies on shelf-life and in the development of new products (MINIM, 2010). The affective tests may also provide more information in addition to that obtained by QDA (BEHRENS; SILVA, 2000; SANTANA et al., 2006).

Changes in sensory characteristics are affected by various types of reactions, such as enzymatic, chemical, and microbiological reactions, whose degradation rate are highly influenced by factors such as storage temperature and time. Therefore, the study on the degradation kinetics of sensory attributes enables us to verify how the rate of changes is influenced by these factors, thus identifying and establishing quantitative cause/effect ratios (TEIXEIRA NETO; VITALI; MOURA, 2004).

The juice of mango cv. Ubá is largely produced and commercialized in the state of Minas Gerais due to the adequate

${ }^{1}$ Department of Food Technology, Federal University of Viçosa - UFV, University Campus, CEP 36570-000, Viçosa, MG, Brazil, e-mail: amramos@ufv.br ${ }^{*}$ Corresponding author 
physicochemical characteristics of the processing presented by the fruits of this variety, as well as for their palatability (BENEVIDES et al., 2008). Therefore, the physical, chemical, and rheological properties of fresh fruit and/or fruit pulp have been the subject of many studies (BENEVIDES et al., 2008; FARAONI et al., 2008, 2009; RIBEIRO et al., 2008; DINIZ, 2009; NEVES, 2010). However, studies related to the assessment of the sensory properties of Ubá mango derivatives are scarce.

This study evaluated the influence of time and temperature of storage on the main sensory characteristics of commercial whole mango juice cv. Ubá.

\section{Material and methods}

Samples of whole mango juice cv. Ubá, of a brand largely commercialized in the state of Minas Gerais, stored in $500 \mathrm{~mL}$ PET bottles, were directly obtained from the industry and immediately taken to the laboratory in order to be stored into incubators with controlled temperature at $25^{\circ} \mathrm{C}$ (control) and 35 and $45{ }^{\circ} \mathrm{C}$ (accelerated conditions), under 24-hour light. The average incident light inside the incubators was of 650 lux, measured by the CA 810 Chauvin Arnoux digital luximeter (Paris, France). Each incubator stored 72 samples.

The experiment was conducted in a split-plot design, and three storage temperatures were completely randomized as plots $\left(25,35\right.$, and $\left.45^{\circ} \mathrm{C}\right)$, panelists as blocks, and seven storage times as sub-plots $(0,20,40,60,80,100$, and 120 days) for samples stored at $25^{\circ} \mathrm{C}$ and $35^{\circ} \mathrm{C}$, and four storage times as sub-plots $\left(0,20,40\right.$ and 60 days) for the samples stored at $45^{\circ} \mathrm{C}$.

\subsection{Microbiological analysis}

Before sensory evaluation, the samples were submitted to microbiological analysis for the determination of coliforms at $45^{\circ} \mathrm{C}$ and Salmonella sp. For the analyses of fecal coliforms, whole mango juice was diluted in peptone water $\left(10^{-1}\right)$. Then, $1 \mathrm{~mL}$ aliquots of this solution were inoculated in Petrifilm ${ }^{\mathrm{TM}}$ plates (3M Company, St. Paul, MN USA). The plates were then incubated at $45^{\circ} \mathrm{C}$ for $24-48$ hours (ASSOCIATION..., 2002). The methodology described by Silva et al. (2007) was used for the analyses of Salmonella sp. Aliquots of $25 \mathrm{~mL}$ of juice samples were added to $225 \mathrm{~mL}$ of lactose broth, which was incubated at $35{ }^{\circ} \mathrm{C}$ for 24 hours. Next, aliquots of $1 \mathrm{~mL}$ were transferred to $10 \mathrm{~mL}$ of selenite-cystine broth and tetrathionate broth, which were incubated for 24 hours at $35^{\circ} \mathrm{C}$ and $42^{\circ} \mathrm{C}$, respectively. After incubation, using a nickel-chrome wire loop, streaks were made onto selective media, brilliant green agar, Salmonella-Shigella agar, and bismuth sulfite agar. The plates were then incubated at $35^{\circ} \mathrm{C}$ for $24-48$ hours.

\subsection{Quantitative descriptive analysis}

The analyses were performed at the Laboratory of Sensory Analysis, Department of Food Technology, Federal University of Viçosa (DTA/UFV). The research project was approved by the University research ethics committee (registration number: 50718458606).
The quantitative descriptive analysis technique was used to select trained panelists eto evaluate sensory changes in sensory quality of whole mango juice.

\section{Recruitment and pre-selection of tasters}

Forty-seven consumers of mango juice who showed interest and availability of time to participate in the study, ability to work with a non-structured scale, knowledge on descriptive terms, and health conditions that would not compromise the analysis were pre-selected. The pre-selection was performed by applying a series of four triangular tests with two samples of mango juice, at $5 \%$ significance level.

\section{Definition of descriptive terms and reference standards and training of tasters}

The Checklist method was used to determine the descriptive words. The pre-selected tasters carried out the samples' assessment using a list of descriptive terms for mango juice, which was proposed by Cavallini and Bolini (2005) and two samples of whole mango juice prepared according to the manufacturer's instructions. One sample was fresh (newly processed) and the other was previously subjected to degradation at $55^{\circ} \mathrm{C}$ for 24 days (changed juice). Only the attributes considered critical by most tasters remained in the final list of descriptive terms.

Next, a meeting was held to define the reference materials (standards) and the endpoints that anchored the 9-cm nonstructured scale (Table 1) used to train the tasters and evaluate the samples.

Three to five training sessions were conducted (as needed for each tester) until all of them proved ability to perceive the attributes that describe the product. In all sessions, the tasters were instructed to read the definition of each attribute and then try and memorize the standards.

\section{Selection of tasters}

The final selection of tasters was carried out from a preliminary test that analyzed the repeatability of the results and the ability to discriminate samples. Therefore, the analysis of variance was performed with two sources of variation (sample and repetition) for each taster and for each attribute. The tasters that showed results with probability values $\mathrm{F}_{\text {SAMPLE }} \geq 0.50$ (low discriminative power) and probability of $\mathrm{F}_{\text {REPETTTION }} \leq 0.05$ (low repeatability) for all descriptive terms were dismissed.

\section{Periodic sensory assessments and analysis of results}

The samples of whole mango juice from each lot stored at the same temperature were mixed in equal parts and diluted with water filtered at a concentration of $40 \%(\mathrm{v} / \mathrm{v})$ of wholemeal juice (optimal concentration of wholemeal juice defined jointly by the tasters for sensory evaluation) and without the addition of sugar to avoid masking changes. The assessments were repeated every 20 days in three repetitions of the same sample arranged in a completely randomized block design using a 9-cm non- 
Table 1. Attributes, definitions, and reference standards for whole mango juice.

\begin{tabular}{|c|c|c|}
\hline Attributes & Definitions & Standards \\
\hline Yelllow & $\begin{array}{l}\text { Sensation produced by the stimulation of the } \\
\text { retina by the wavelengths of light rays. Yellow } \\
\text { is the characteristic color of mango-juice. }\end{array}$ & $\begin{array}{l}\text { Dark: Whole mango juice diluted in water at the concentration of } \\
40 \%(\mathrm{v} / \mathrm{v}) \text { with the addition of } 0.6 \%(\mathrm{p} / \mathrm{v}) \text { of caramel dye. } \\
\text { Light: Whole mango juice diluted in water at the concentration of } \\
5 \%(\mathrm{v} / \mathrm{v}) \text {. }\end{array}$ \\
\hline Aroma of mango juice & $\begin{array}{l}\text { Characteristic aroma of volatile substances } \\
\text { of mango fruit. }\end{array}$ & $\begin{array}{l}\text { Non-characteristic: whole mango juice stored at the temperature of } \\
55^{\circ} \mathrm{C} \text { for } 24 \text { days and not diluted. } \\
\text { Characteristic: Whole mango juice, fresh, not diluted. }\end{array}$ \\
\hline Consistency & $\begin{array}{l}\text { Represents food thickness in the mouth } \\
\text { after being compressed up and down by the } \\
\text { movement of the tongue against the palate. }\end{array}$ & $\begin{array}{l}\text { Little: Whole mango juice diluted in water at the concentration of } \\
20 \%(\mathrm{v} / \mathrm{v}) \text {. } \\
\text { Much: Whole mango juice diluted in water at the concentration of } \\
60 \%(\mathrm{v} / \mathrm{v}) \text {. }\end{array}$ \\
\hline
\end{tabular}

structured scale (Figure 1). For the completion of assessments, the cutoff value of 4.5 was determined for the attribute flavor. The data were subjected to analysis of variance (ANOVA) and linear regression against time using the SAS (Statistical Analysis System - SAS Institute Inc., Cary, NC, USA), version 9.1.

\subsection{Determination of kinetic parameters}

The QDA data underwent linear regression analysis against time for the adjustment of the model and to determine the degradation rate constants $(k)$. The suitability of models was evaluated by the analysis of lack of adjustment and by the determination coefficients $\left(\mathrm{R}^{2}\right)$.

The temperature acceleration factor $\left(\mathrm{Q}_{10}\right)$ was determined from the quotient between the values of kinetic constants at $45^{\circ} \mathrm{C}$ and $35^{\circ} \mathrm{C}$ (Equation 1), as described by Labuza and Schmidl (1985).

$Q_{10}=\frac{k_{45^{\circ} \mathrm{C}}}{k_{35^{\circ} \mathrm{C}}}$

where $\mathrm{k}$ is the degradation rate constant.

To determine the activation energy $\left(E_{a}\right)$, Equation 2 was used, as described by Teixeira Neto, Vitali and Moura (2004).

$E_{a}=0,46 \times T^{2} \times \log Q_{10}$

where $\mathrm{T}$ is the absolute temperature $(\mathrm{K})$.

\subsection{Correlations between the physicochemical and sensory characteristics}

In order to assess the correlations between the physicochemical and sensory characteristics of whole Ubá mango juice, analyses were carried out to determine the content of vitamin $\mathrm{C}$ and instrumental color coordinates $\left(\mathrm{L}^{\star}\right.$ and $\left.\Delta \mathrm{E}^{\star}\right)$ during the storage of the products.
QDA

Name: Date:

Please, taste the sample and mark with a vertical trace in the scales below the position that indicate the intensityof the characteristics analyzed.

Sample code:

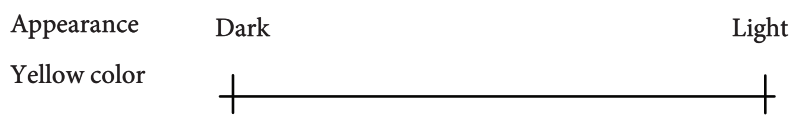

Aroma
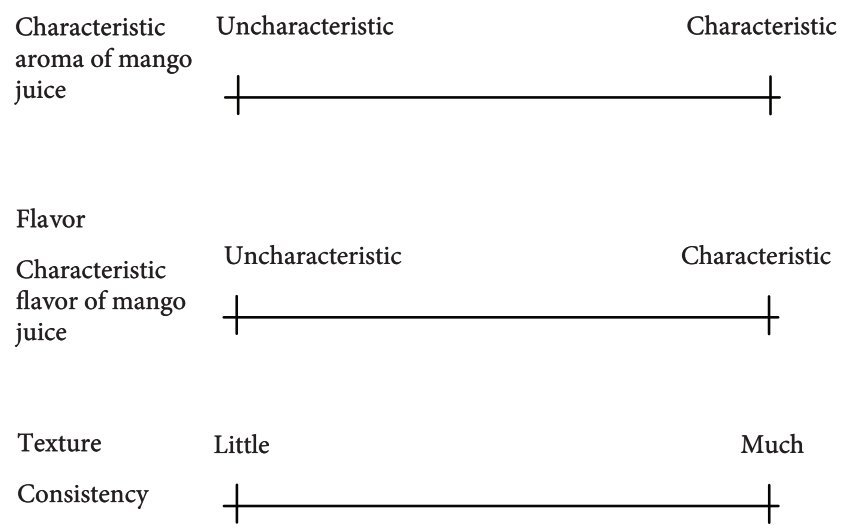

Figure 1. Instruction card used in the preliminary test and sensory evaluations.

The determination of vitamin $\mathrm{C}$ content was carried out using the AOAC official method, which is based on the reduction of 2,6-dichlorophenol indophenol by a solution of ascorbic acid modified by Benassi (1990), with the replacement of metaphosphoric acid with oxalic acid as solvent. The determinations of instrumental color coordinates $\left(\mathrm{L}^{*}, \mathrm{a}^{*}\right.$ and $\left.\mathrm{b}^{*}\right)$ were made using the Minolta color reader CR-10 colorimeter, CIELAB system. The total color difference $\left(\Delta \mathrm{E}^{*}\right)$ was calculated 
according to Equation 3 (LOPES; MATTIETTO; MENEZES, 2005):

$\Delta E^{*}=\sqrt{\left(\Delta L^{*}\right)^{2}+(\Delta a *)^{2}+\left(\Delta b^{*}\right)^{2}}$

where $\Delta$ is the variation between each color coordinate of the initial sample (zero time) and the stored sample.

The Pearson correlation coefficients were determined using the SAS Institute ${ }^{\varpi}$ software system, version 9.1 to assess the significance of the correlations.

\subsection{Sensory acceptance evaluation}

In addition to the quantitative descriptive analysis, acceptance tests were conducted at intervals of 20 days. In each session, 50 untrained panelists were selected based on their mango juice consumption availability to perform the analyses. For these tests, the samples were prepared according to the manufacturer's recommendations: 2 parts of whole juice to 8 parts water. The concentration of sugar used to prepare the juice was $8 \%$, determined by preliminary tests (unpublished data), which was also used by Umbelino (2005). The samples were coded and served at $10^{\circ} \mathrm{C}$. A nine-point hedonic scale, ranging from 1 (extremely dislike) to 9 (extremely like) was used, in which the taster was asked about his overall impression of the product. Data were submitted to regression analysis using the SAS software.

\section{Results and discussion}

Throughout the study, the samples showed good microbiological stability at the three storage temperatures studied, and the presence of thermo tolerant coliform and Salmonella sp. was not observed, thus complying with the legislation (BRASIL, 2001).

\subsection{Quantitative descriptive analysis}

Forty-eight tasters were selected to compose the sensory panel, of which 33 achieved at least $75 \%$ correct responses in the series of four triangular tests ( 20 women and 13 men). From the list of descriptive terms for mango juice, the pre-selected tasters considered the following attributes critical: yellow color, characteristic aroma, flavor, and consistency.

Out of the 33 tasters pre-selected in the triangular test series, only 22 participated in the final selection. Four tasters that showed low ability to discriminate the samples at $5 \%$ significance were dismissed. None of the tasters showed low repeatability in the results. Among the tasters selected, four did not have availability of time and did not attend the sensory evaluations. Therefore, the panel that evaluated mango juice during the storage period was composed of 14 selected tasters.

The panelists' behavior and perception regarding the attribute flavor of mango juice during storage is shown in Figure 2. A significant effect $(\mathrm{p}<0.05)$ of storage time on the flavor of the juices stored at $35^{\circ} \mathrm{C}$ and $45^{\circ} \mathrm{C}$ was observed, while the average score assigned by the panelists at zero time was 7.27. The values of flavor degradation rate constants $(\mathrm{k})$, determined

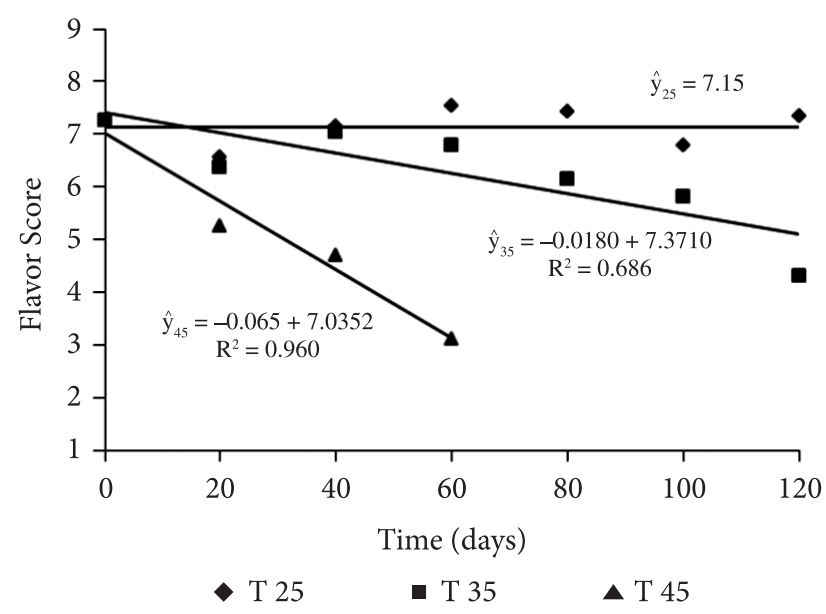

Figure 2. Behavior of the flavor scores of whole mango juice stored at $25^{\circ} \mathrm{C}, 35^{\circ} \mathrm{C}$ and $45^{\circ} \mathrm{C}$.

from the linear regression equations, were 0.0180 and 0.065 days $^{-1}$ for temperatures of 35 and $45{ }^{\circ} \mathrm{C}$, respectively. These values are consistent with those found in foods of plant origin, such as those obtained by Grizotto et al. (2006) for restructured and dried papaya, who found a constant equal to 0.0398 days $^{-1}$ at $35^{\circ} \mathrm{C}$ for overall quality. Moura et al. (2007) found constants equal to 0.0141 and 0.0282 days $^{-1}$ for the flavor degradation of dehydrated apples stored at 25 and $35^{\circ} \mathrm{C}$, respectively.

The change observed at $25^{\circ} \mathrm{C}$ was not significant $(p>0.05)$, which shows good stability of the product under normal storage conditions. The maintenance of flavor in juices depends mainly on the destruction of certain enzymes during heat treatment. Thus, the fact that the product was previously pasteurized probably contributed to the maintenance of flavor at room temperature. Moreover, temperatures of 35 and $45^{\circ} \mathrm{C}$ probably caused an increased rate of degradation of thermo sensible nutrients present in mango juice, such as vitamin $C$, which, when oxidized, resulted in off-flavor (AL-ZUBAIDY; KHALIL, 2007).

The behavior observed for aroma (Figure 3) was similar to that observed for flavor, and the degradation rate constants at 35 and $45{ }^{\circ} \mathrm{C}$ were 0.0125 and 0.052 days $^{-1}$, respectively. Changes during storage were described by panelists as "smells like the juice was rusty or even cooked". This was also observed by Argaiz and López-Melo (1996), who verified the appearance of taste and aroma of "cooked juice" in nectar and purees of mango and papaya subjected to heat treatment.

Changes in color over time, reported by the panelists as a progressive darkening and the consequent loss of the characteristic yellow color, are shown in Figure 4. The kinetic constants for the reduction in color scores of the whole mango juice in accelerated storage conditions were equal to 0.0089 days $^{-1}\left(35^{\circ} \mathrm{C}\right)$ and 0.0241 days $^{-1}\left(45^{\circ} \mathrm{C}\right)$. Therefore, as observed for the flavor and aroma, there was also no significant changes in the scores for the samples stored at $25^{\circ} \mathrm{C}(\mathrm{p}>0.05)$. These color changes may have been caused by non-enzymatic oxidative degradation of nutrients, such as carotenoids, vitamin C, and other phenolic compounds, which leads to the formation of 


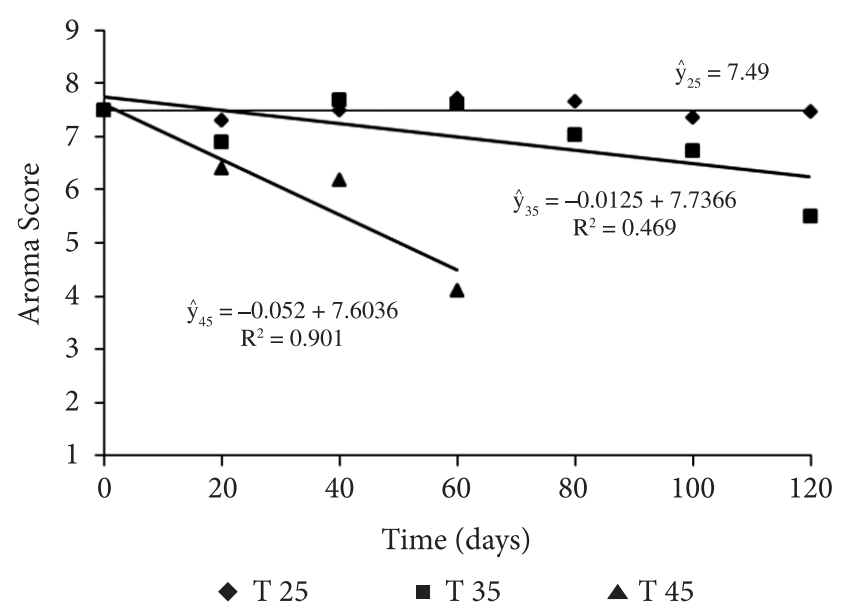

Figure 3. Behavior of the aroma scores of whole mango juice stored at $25^{\circ} \mathrm{C}, 35^{\circ} \mathrm{C}$ and $45^{\circ} \mathrm{C}$.

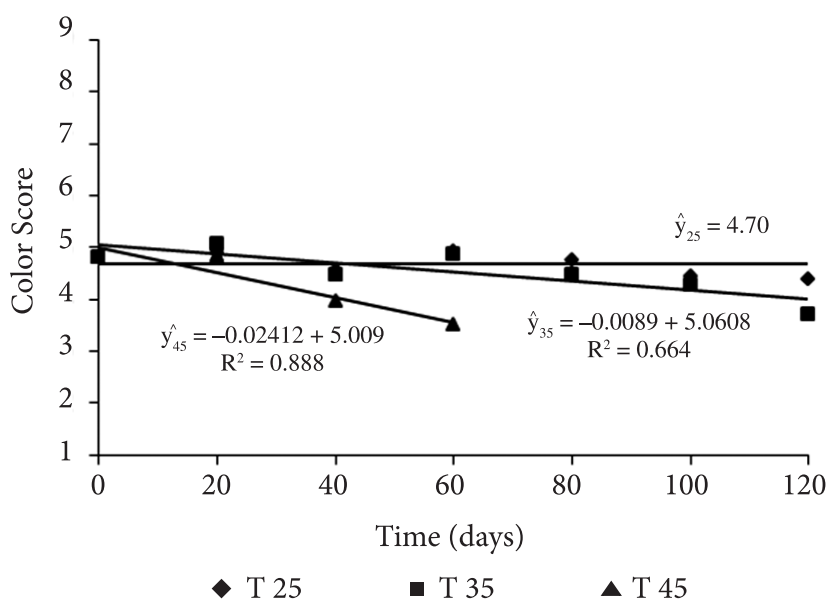

Figure 4. Behavior of the color scores of whole mango juice stored at $25^{\circ} \mathrm{C}, 35^{\circ} \mathrm{C}$ and $45^{\circ} \mathrm{C}$.

dark pigments in the product, thus affecting quality and limiting the shelf-life (AL-ZUBAIDY; KHALIL, 2007; TEIXEIRA et al., 2006). The oxidation may have been triggered by the passage of light through the transparent juice container, thus allowing its catalytic action on the oxidation of these nutrients (MATTIETTO; LOPES; MENEZES, 2007).

It was found that the consistency of juice stored at different temperatures remained constant throughout the study, and the average score was 5 , close to the midpoint of the nonstructured scale. Consistency maintenance is an indication that the heat processing of the product was effective in inactivating the enzymes responsible for changes in consistency in fruit juices, such as pectinesterase, which catalyze the degradation of pectin to pectic acid and methanol (LOPES; MATTIETTO; MENEZES, 2005).

\subsection{Determination of kinetic parameters}

The $Q_{10}$ values obtained for the sensory attributes of mango juice were 3.61 (flavor), 2.71 (color), and 4.16 (aroma), while the activation energies (Ea) were $22.80 \mathrm{kcal}^{\mathrm{mol}}{ }^{-1}$ (taste),
$17.70 \mathrm{kcal}^{\mathrm{mol}}{ }^{-1}$ (color), and $25.31 \mathrm{kcal}^{\mathrm{mol}}{ }^{-1}$ (aroma). The kinetic parameters $\mathrm{E}_{\mathrm{a}}$ and $\mathrm{Q}_{10}$ obtained in this study are consistent with the values for general sensory quality for foods of plant origin reported by Teixeira Neto, Vitali and Moura (2004). According to Lund (1979), the values of $\mathrm{E}_{\mathrm{a}}$ for these products are approximately $10-30 \mathrm{kcal}^{\mathrm{mol}}{ }^{-1}$. Based on the parameters obtained, the attributes flavor and aroma were more dependent on the temperature of storage than color. That is, color change was less accelerated with increased temperature.

Similar results were obtained by Ferreira et al. (1999), for color degradation in water soluble annatto solution ( $23.9 \mathrm{kcal}_{\mathrm{mol}}{ }^{-1}$ ), and Grizotto et al. (2006), for the overall quality of fruit made from papaya $\left(19.89 \mathrm{kcal}^{\mathrm{mol}} \mathrm{m}^{-1}\right)$. Moura et al. (2001) found values for activation energy of $8.0 \mathrm{kcal} . \mathrm{mol} \mathrm{q}^{-1}$ and of 1.55 for instrumental color of strawberry pulp. No data was found in the literature concerning the degradation kinetics of sensory attributes of mango juice.

\subsection{Correlations between physicochemical and sensory characteristics}

Table 2 shows the Pearson correlation coefficients between the sensory characteristics of whole mango juice, assessed by trained staff, and the concentration of vitamin $\mathrm{C}$ and instrumental color coordinates $\left(\mathrm{L}^{*}\right.$ and $\left.\Delta \mathrm{E}^{\star}\right)$.

The concentration of vitamin $\mathrm{C}$ in juices stored at 25,35 , and $45^{\circ} \mathrm{C}$ ranged from $26.8 \mathrm{mg} / 100 \mathrm{~mL}$ (initial concentration) to $16.89\left(25^{\circ} \mathrm{C}\right), 10.34\left(35^{\circ} \mathrm{C}\right)$, and $9.85 \mathrm{mg} / 100 \mathrm{~mL}\left(45^{\circ} \mathrm{C}\right)$, at the end of the respective days of storage, which corresponds to a loss of $37,61.4$, and $63.2 \%$, respectively. There was also a significant increase in the values of $\Delta \mathrm{E}{ }^{*}$ for the products stored at $35^{\circ} \mathrm{C}$ and $45^{\circ} \mathrm{C}(\mathrm{p}<0.05)$. Significant correlations were observed between the concentration of vitamin $C$ and the color coordinates $\mathrm{L}^{\star}(0.91, \mathrm{p}<0.01)$ and $\Delta \mathrm{E}^{\star}(-0.88, \mathrm{p}<0.01)$. This result demonstrates that the degradation of vitamin $\mathrm{C}$ is related to the darkening of mango juice (lower brightness) and loss of the characteristic color of the product (increased $\Delta \mathrm{E}^{*}$ values). This browning results from the formation of compounds such as furfural, and hydroxymethylfurfural (HMF), which generate dark pigments causing the darkening of the product (AL-ZUBAIDY; KHALIL, 2007; LOPES, 2005; TEIXEIRA et al., 2006). It is also known that, besides darkening, these compounds cause the generation of unpleasant flavors in juices during storage (TEIXEIRA; MONTEIRO, 2006; MATTIETTO; LOPES; MENEZES, 2007). In fact, there was a significant positive correlation $(\mathrm{p}<0.01)$ between the degradation of vitamin $\mathrm{C}$ and changes in color, aroma, and flavor evaluated by the trained tasters (Table 2). Since the degradation of vitamin $\mathrm{C}$ is directly related to reduced fruit juice quality (TIWARI et al., 2009; TORREGROSA et al., 2006), it can be said that the quantitative descriptive analysis proved a useful tool in studies of shelf-life.

There was a significant correlation $(p<0.01)$ between sensory color degradation and changes in color coordinates $L^{*}(0.82)$ and $\Delta E^{*}(-0.84)$ indicating that the loss of the characteristic yellow color is related with decreased brightness and increased total color difference. Similarly, significant 
Table 2. Pearson correlation coefficients obtained between the physicochemical and sensory characteristics of whole mango juice.

\begin{tabular}{lcccccc}
\hline & Vitamin C & $\mathrm{L}^{*}$ & $\Delta \mathrm{E}^{*}$ & Color & Aroma & Flavor \\
\hline Vitamin C & 1.00 & $0.91^{* *}$ & $-0.88^{* *}$ & $0.78^{* *}$ & $0.67^{* *}$ & $0.72^{* *}$ \\
$\mathrm{~L}^{*}$ & - & 1.00 & $-0.95^{* *}$ & $0.82^{* *}$ & $0.78^{* *}$ & $0.83^{* *}$ \\
$\Delta \mathrm{E}^{*}$ & - & - & 1.00 & $-0.84^{*}$ & $-0.67^{* *}$ & $-0.68^{* *}$ \\
Color & - & - & - & 1.00 & $0.80^{* *}$ & $0.78^{* *}$ \\
Aroma & - & - & - & - & 1.00 & $0.97^{* *}$ \\
Flavor & - & - & - & - & - & 1.00 \\
\hline
\end{tabular}

Vit C = Vitamin C; ${ }^{*}$ Significant at $5 \%$ de probability; ${ }^{* *}$ Significant at $1 \%$ probability.

correlations $(p<0.01)$ were observed between the values of $L^{*}$ and $\Delta \mathrm{E}^{*}$ and the changes in the attributes flavor and aroma.

With respect to sensory attributes, there was a significant $(\mathrm{p}<0.01)$ positive correlation between color and flavor (0.78); color and aroma (0.80); and between aroma and flavor (0.97).These results demonstrate that the reactions that cause degradation of whole mango juice cause undesirable changes in these three characteristics, and the change in one of them, such as color, for example, indicates that the other has also been affected (aroma and flavor).

\subsection{Evaluation of sensory acceptance}

There were no significant effects of time and storage temperature on overall impression by consumers $(\mathrm{p}>0.05)$, as shown in Figure 5. The average scores fell between the terms "I liked slightly" and "I liked moderately".

It is worthy to mention, however, that for the acceptance tests, the products were formulated as recommended by the manufacturer: 2 pieces of whole mango juice to 8 parts water with $8 \%$ sugar content (UMBELINO, 2005).

Therefore, when the samples were evaluated by consumers and formulated as recommended by the manufacturer, the differences detected by the trained panel went unnoticed, and the more and less degraded products had the same hedonic rating. At least two factors may have contributed to this: the addition of sugar to the product, in order to prepare the nectar, which may have masked the changes perceived by trained panelists, who evaluated the concentrated juice, and the fact that the consumers had no knowledge of the changed sensory characteristics such as aroma or flavor in the product (ARAUJO; SILVA; MINIM, 2003). Therefore, the mango juice may have characteristics such as flavor of overripe fruit or a slightly oxidized taste, as perceived by trained panelists as quality attributes, but consumers may not be able to detect these changes.

In the present study, the nutritional loss observed in the product was not sufficient for the perception of changes in sensory quality by the consumers. In other words, the fact that the consumers did not notice changes in the overall acceptance of the juice does not necessarily mean that they preserve a satisfactory quality when taking into account nutritional quality, for example. When compared with the acceptance test, the use of QDA proved more appropriate for estimating the loss of product quality during storage, such as in studies to assess shelf-life.

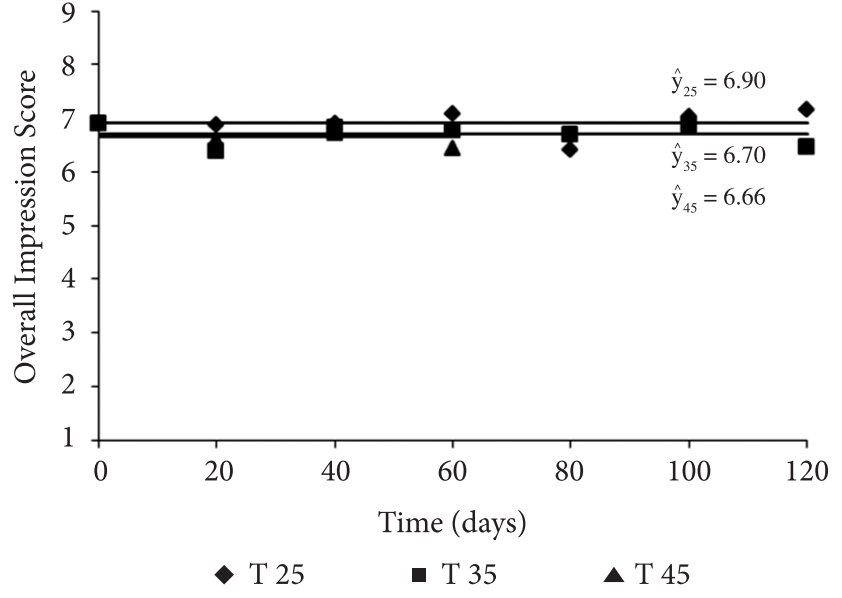

Figure 5. Behavior of the overall impression scores of consumers of whole mango juice stored at $25^{\circ} \mathrm{C}, 35^{\circ} \mathrm{C}$ and $45^{\circ} \mathrm{C}$.

\section{Conclusions}

The characteristics of flavor, aroma, and color, as assessed by trained panel were affected by storage time and temperature showing the importance of these attributes on the quality of mango juice. Consumers, however, did not perceive differences regarding the acceptance of the products stored at different temperatures over time. This may have occurred because the consumers may consume juices with a lightly oxidized flavor or a significant loss in the nutritional quality such as the degradation of vitamin C.

The results found by a trained staff can be correlated with changes in the nutritional quality of the juice, including loss of vitamin $C$, which is a parameter widely used to estimate the shelf life of foods from plants. Thus, it can be said that quantitative descriptive analysis proved a good alternative for studies to assess shelf-life of foods.

\section{Acknowledgements}

The authors thank FAPEMIG and CNPq for the financial support.

\section{References}

AL-ZUBAIDY, M. M. I.; KHALIL, R. A. Kinetic and prediction studies of ascorbic acid degradation in normal and concentrate local lemon juice during storage. Food Chemistry, v. 101, n. 1, p. 254-259, 2007. http://dx.doi.org/10.1016/j.foodchem.2006.01.024

ARAÚJO, F. B.; SILVA, P. H. A.; MINIM, V. P. R. Perfil sensorial e composição físico-química de cervejas provenientes de dois segmentos do mercado brasileiro. Ciência e Tecnologia de Alimentos, v. 23, n. 2, p. 121-128, 2003. http://dx.doi.org/10.1590/ S0101-20612003000200004

ARGAIZ, A.; LÓPEZ-MELO, A. Kinetics of first change on flavour, cooked flavour development and pectinesterase inactivation on mango and papaya nectars and purees. Food Processing, v. 4, p. 145-150, 1996.

ASSOCIATION OF OFFICIAL ANALYTICAL CHEMISTS - AOAC. Official methods of analysis of AOAC. $17 \mathrm{th}$ ed. Washington, 2002. 570 p. 
BEHRENS, J. H.; SILVA, M. A. A. P. Perfil sensorial de vinhos brancos varietais brasileiros através de análise descritiva quantitativa. Ciência e Tecnologia de Alimentos, v. 20, n. 1, p. 60-67, 2000. http://dx.doi.org/10.1590/S0101-20612000000100013

BENASSI, M. T. Análise dos estudos de diferentes parâmetros na estabilidade de vitamina $C$ em vegetais processados. $1990.159 \mathrm{f}$. Dissertação (Mestrado em Ciencia de Alimentos)-Faculdade de Engenharia de Alimentos, Universidade Estadual de Campinas, Campinas, 1990.

BENEVIDES, S. D. et al. Qualidade da manga e polpa da manga Ubá. Ciência e Tecnologia de Alimentos, v. 28, n. 3, p. 571-578, 2008. http://dx.doi.org/10.1590/S0101-20612008000300011

BRASIL. Agência Nacional de Vigilância Sanitária. Resolução - RDC $\mathrm{n}^{\circ} 12$, de 02 de janeiro de 2001. Regulamento Técnico sobre Padrões Microbiológicos para Alimentos. Diário Oficial da República Federativa do Brasil, Brasília, DF, jan. 2001.

CAVAllini, D. C. U.; BOLINI, H. M. A. Perfil sensorial de suco de manga adoçado com diferentes edulcorantes e com sacarose. Alimentos e Nutrição, Araraquara, v. 16, n. 4, p. 327-336, 2005.

DINIZ, M. D. M. S. Caracterização do comportamento reológico e determinação de propriedades termofísicas de polpa de manga Ubá. 2009. 87 f. Dissertação (Mestre em Ciência e Tecnologia de Alimentos)-Universidade Federal de Viçosa, Viçosa, 2009.

FARAONI, A. S.; RAMOS, A. M.; STRINGHETA, P. S. Caracterização da manga orgânica cultivar Ubá. Revista Brasileira de Produtos Agroindustriais, v. 11, n. 1, p. 9-14, 2009.

FARAONI, A. S. et al. Efeito dos métodos de conservação, tipos de embalagem e tempo de estocagem na coloração de polpa de manga "Ubá" produzida em sistema orgânico. Revista Ceres, v. 55, n. 6, p. 504-511, 2008.

FERREIRA, V. L. P. et al. Cinética da degradação da cor de solução hidrossolúvel comercial de urucum, submetida a tratamentos térmicos. Ciência e Tecnologia de Alimentos, v.19, n. 1, p. 37-42, 1999. http://dx.doi.org/10.1590/S010120611999000100010

GRIZOTTO, R. K. et al. Estudo da vida-de-prateleira de fruta estruturada e desidratada obtida de polpa concentrada de mamão. Ciência e Tecnologia de Alimentos, v. 26, n. 3, p. 709-714, 2006. http://dx.doi.org/10.1590/S0101-20612006000300035

LABUZA, T. P.; SCHMIDL, M. K. Accelerated shelf life testing of foods. Food Technology, v. 39, n. 9, p. 57-64, 1985.

LOPES, A. S. Pitanga e acerola: estudo de processamento, estabilidade e formulação de néctar misto. 2005. 193 f. Tese (Doutorado em Tecnologia de Alimentos)-Faculdade de Engenharia de Alimentos, Universidade Estadual de Campinas, Campinas, 2005.

LOPES, A. S.; MATTIETTO, R. A.; MENEZES, H. C. Estabilidade da polpa de pitanga sob congelamento. Ciência e Tecnologia de Alimentos, v. 25, n. 3, p. 553-559, 2005. http://dx.doi.org/10.1590/ S0101-20612005000300026

LUND, D. B. Effect of commercial processing on nutrients. Food Technology, v. 33, n. 2, p. 28-35, 1979.

MARANGONI, C.; MOURA, N. F. Sensory profile of Italian salami with coriander (Coriandrum sativum L.) essential oil. Ciência e Tecnologia de Alimentos, v. 31, n. 1, p. 119-123, 2011. http://dx.doi. org/10.1590/S0101-20612011000100016

MASCARENHAS, R. J. et al. Avaliação sensorial de uvas de mesa produzidas no Vale do São Francisco e comercializadas em João Pessoa - PB. Revista Brasileira de Fruticultura, v. 32, n. 4, p. 993-1000, 2010. http://dx.doi.org/10.1590/S010029452011005000012

MATTIETTO, R. A. et al. Estabilidade do néctar misto de cajá e umbu. Ciência e Tecnologia de Alimentos, v. 27, n. 3, p. 456-463, 2007. http://dx.doi.org/10.1590/S0101-20612007000300006
MIGUEL, A. C. A. et al. Perfil sensorial e aceitação de melão amarelo minimamente processado submetido a tratamentos químicos. Ciência e Tecnologia de Alimentos, v. 30, n. 3, p. 589-598, 2010. http://dx.doi.org/10.1590/S0101-20612010000300004

MINIM, V. P. R. Análise Sensorial: Estudos dos consumidores. 2. ed. Viçosa: Editora UFV, 2010. v. 1, 308 p.

MOSKOWITZ, H. R. Applied sensory analysis of foods. Boca Ratton: CRC Press, 1988. v. 1, 259 p.

MOURA, S. C. S. R. et al. Determinação da vida-de-prateleira de maçãpassa por testes acelerados. Ciência e Tecnologia de Alimentos, Campinas, v. 27, n. 1, p. 141-148, 2007. http://dx.doi.org/10.1590/ S0101-20612007000100025

MOURA, S. C. S. R. et al. Cinética de degradação de polpas de morango. Brazilian Journal of Food Technology, v. 4, p. 115121, 2001.

NEVES, E. G. F. Caracterização da produção e qualidade da manga "Ubá" e goiaba e validação de um sistema de rastreabilidade para a fruticultura da Zona da Mata mineira. 2010. 210 f. Tese (Doutorado em Ciência e Tecnologia de Alimentos)-Universidade Federal de Viçosa, Viçosa, 2010.

RIBEIRO, S. M. R. et al. Phenolic compounds and antioxidant capacity of Brazilian mango (Mangifera indica L.) varieties. Food Chemistry, v. 110, n. 3, p. $620-626,2008$. http://dx.doi.org/10.1016/j. foodchem.2008.02.067

SANTANA, L. R. R. et al. Perfil Sensorial de Iogurte Light, Sabor Pêssego. Ciência e Tecnologia de Alimentos, v. 26, n. 3, p. 619-625, 2006. http://dx.doi.org/10.1590/S0101-20612006000300021

SILVA, N. et al. Manual de métodos de análise microbiológica de alimentos. 3. ed. São Paulo: Livraria Varela, 2007. 535 p.

TEIXEIRA, J. et al. Degradação do ácido ascórbico em goiabada industrializada submetida a diferentes condições de estocagem. Alimentos e Nutrição, v. 17, n. 3, p. 281-286, 2006.

TEIXEIRA, M.; MONTEIRO, M. Degradação da vitamina c em suco de fruta. Alimentos e Nutrição, v. 17, n. 2, p. 219-227, 2006.

TEIXEIRA NETO, R. O.; VITALI, A. A.; MOURA, S. C. S. R. Introdução à cinética de reação em alimentos. In: MOURA, S. C. S. R.; GERMER, S. P. M. (Eds.). Reações de Transformação e Vidade-prateleira de Alimentos Processados. Campinas: ITAL, 2004. cap. 3, p. 25-47.

TIWARI, B. K. et al. Ascorbic acid degradation kinetics of sonicated orange juice during storage and comparison with thermally pasteurised juice. Food Science and Technology, v. 42, n. 3, p. 700-704, 2009.

TORREGROSA, F. et al. Ascorbic acid stability during refrigerated storage of orange-carrot juice treated by high pulsed electric field and comparison with pasteurised juice. Journal of Food Engineering, v. 73, n. 4, p. 339-345, 2006. http://dx.doi. org/10.1016/j.jfoodeng.2005.01.034

UMBELINO, D. C. Caracterização sensorial por análise descritiva quantitativa e análise tempo-intensidade de suco e de polpa de manga (Mngífera indica 1.) adoçados com diferentes edulcorantes. 2005. 190 f. Tese (Doutorado em Alimentos e Nutrição)-Faculdade de Engenharia de Alimentos, Universidade Estadual de Campinas, Campinas, 2005.

VILANOVA, M.; MASA, A.; TARDAGUILA, J. Evaluation of the aroma descriptors variability in Spanish grape cultivars by a quantitative descriptive analysis. Euphytica, v. 165, n. 2, p. 383-389, 2009. http:// dx.doi.org/10.1007/s10681-008-9801-7 